\title{
HASANAGINICA - USMENA BALADA U DRAMSKOM STVARALAŠTVU NA PRIMJERU DRAMSKIH TEKSTOVA ALIJE ISAKOVIĆA I NIJAZA ALISPAHIĆA
}

\section{Sažetak}

Historijska podloga za dramske tekstove o Hasanaginici su najčuvenija bošnjačka narodna balada, te mnogobrojne, raširene legende i usmene predaje. Sama balada o nesretnoj Hasanaginici nastala je u Imotskoj krajini, a osnovni tok baladne radnje dešava se u mjestu Vrdol (današnjiem Zagvozdu i Župi) gdje je, po junaštvu čuveni, Hasan-aga Arapović imao velika imanja i kule koje je najvjerovatnije zadobio kroz svoje nadaleko čuveno vojevanje. Vrijeme radnje se može odrediti kao kraj prve polovine XVII vijeka, za vrijeme poznatog Kandijskog rata, kada je došlo do potresanja i pomijeranja granica gigantskoga Osmanskoga carstva. Nesretni splet okolnosti izazvan prvenstveno socijalno-kulturološkim uzrocima će Hasanaginicu gurnuti u emocionalnu provaliju i tragičnu smrt žene-majke. I kada se saberu historijski dokumenti, narodne legende, i podaci koje nam donosi sama balada, teško je znati šta se od ovoga stvarno dogodilo, a šta je "narod pridodao". Možda su se dogadaji odvijali autentično onima u baladi, a možda se u stvarnosti desio samo poneki fragment od svega onog ispjevanog $i$ ispripovijedanog, medutim, ovakva duboka tragedija, o bolnoj smrti nesretne žene-majke zarobljene u nepravednom i krutom "kastinskom" sistemu, u kojem je djelovala samo kao svojina i predmet plemićkog "nama", bilo muža, bilo brata, svoju idealnu umjetničku preregistraciju pronaći će u bošnjačkoj dramskoj književnosti. Svoju inspiraciju u ovoj svjetski poznatoj baladi pronašla su dva vrhunska bošnjačka dramska pisca, Alija Isaković i Nijaz Alispahić, što je rezultiralo nastankom dva vrlo značajna historijska dramska teksta, koji svojim estetskim vrijednostima zauzimaju same vrhove ove književne vrste, ali ujedno $i$ ukazuju na neprekinuti kontinuitet $i$ brižljivo njegovane tradicionalne vrijednosti bošnjačke književnosti općenito. Oba dramska autora su se vješto poslužila specifičnim konstruktivnim postupkom semantiziranjem dramskog vremena, jer odabir bilo koje historijske epohe ima tačno predodređenu 
semantičku funkciju pri prezentaciji dramskog teksta. Zahvaljujuci dramskoj multimedijalnosti, tako imamo paralelni tok dvije konkretne vremenske velicine i one su uvijek kroz prožimanje unutrašnjeg komunikacijskog sistema sa vanjskim komunikacijskim sistemom u svojevrsnoj simbiozi.

Ključne riječi: Hasanaginica, Hasan-aga Arapović, beg Pintorović, imotski kadija, kastinski poredak, klasne i kulturološke granice, žena kao svojina, Alija Isaković, Nijaz Alispahić, balada, dramski tekst, preregistracija diskursa, semantiziranje dramskog vremena

Osnovni konstruktivni princip Isakovićeve poetike je, prije svega, dvojnost prezenta, koja se može definirati kao međuzavisnost "dvaju" prezenta ("prezenta" promatranoga svijeta i života, i prezenta u jeziku). I u svom dramskom opusu, Isaković je zagledan u prošlost, pa se njegovi dramski tekstovi, iako je u njima gramatička dominanta isključivo prezent, uvijek mogu definirati kao tematska korespondencija prošlosti sa suvremenošću. Korespondirajući sa suvremenošću, on se vezuje za našu bošnjačku književnu, narodnu i kulturnu tradiciju, koju, oblikuje na jedan nov i originalan način, izvlačeći univerzalne poruke i smisao, te ukazujući na nedvojbenu ljepotu tradicionalne bošnjačke književnosti, koja je u Isakovićevom vremenu bila uveliko zanemarivana. Tako se Isakovićeva dramska poetika poklapa sa temeljnim postulatima neohistorijske dramaturgije, gdje je, u slučaju analize historijskih dramskih tekstova najvažnije je uočiti koje su relacije uspostavljene između vremena prezenta (vremena izvođenja dramskog teksta) i vremena prošlog koje se razjašnjava i secira u dramskom tekstu, jer su ta vremena nužno slivena u jedno nadvrijeme koje predstavlja dekonstruiranu problematiku recipijentove sadašnjosti, tako da to vrijeme uvijek biva reprezent dramskih ideja. Takva paralelizacija vremena uglavnom je vršena na osnovu demistifikacije nekog konkretnog prošlog vremena koje je iskazano kao ono najpogodnije za povlačenje paralele sa vremenom sadašnjim, pa su reprezentovana značenja uvijek simbiotički slivena iz svojevrsnog vremenskog jedinstva koje tek sjedinjeno progovara o konkretnom problemu koje dramski tekstovi razrađuju. 
Sve Isakovićeve drame, osim drame Hasanaginica, se kreću u istom vremenskom razdoblju, između dva svjetska rata, ali gotovo sve tematiziraju različitu problematiku. Kao dramski pisac, Isaković će se realizirati krajem sedamdesetih i početkom osamdesetih godina prošlog vijeka i on spada u grupu (ponira) dramskih pisaca koji baš u tom, periodu istražuju moderni teatar i preispituju utjecaje modernog teatra na tradicionalnu domaću književnost. Tako se Isakovićeve drame odlikuju dokidanjem do tada forsirane realističke tradicije, te se on, kao i većina dramskih pisaca toga doba, bavi raznim scenskim ispitivanjima, pa su njegove drame prepune naturalističkih, neosimbolističkih i egzistencijalističkih elemenata, što je naročito izraženo dramama To i Generalijum. Ono što je Isakovića prvenstveno izdiferenciralo kao dramskog pisca bilo je to da se on kao dramski autor prvenstveno izgrađuje kroz radio-drame, pa su njegovi dramski tekstovi obilježeni tom specifičnom vrstom, tako da su njegove drame izgrađene od pomno razrađenih dijaloga, punih dramskog intenziteta i psihološke težine, koji tkaju intenzivan dramski naboj.

Isakovićeva drama Hasanaginica obuhvata vrijeme kraja prve polovine XVII vijeka, vrijeme čuvenog Kandijskog rata u kojem se nazire potresanje i pomijeranje granica gigantskoga Osmanskoga carstva. Historijska podloga za dramski tekst o Hasanaginici su balada i mnogobrojne legende. Balada o nesretnoj Hasanaginici nastala je u Imotskoj krajini, na mjestu odakle se u daljini naziru vrletni i surovi visovi divlje planine Biokovo. Osnovni tok baladne radnje dešava se u mjestu Vrdol, (današnji Zagvozd i Župa), gdje je po junaštvu čuveni Hasan-aga Arapović imao velika imanja i kule, koje je najvjerovatnije zadobio kroz svoje nadaleko čuveno vojevanje. U narodu se vjeruje da temelji Hasan-agine kule postoje i danas, kao i mjesto gdje je Hasanaginica sahranjena. Po narodnoj predaji, njen mezar leži u blizini ruševina kule, na simboličnom mjestu, pored tri bunara, za koje se vjeruje da je ova po porijeklu i čuvenoj ljepoti obilježena žena iz njih zahvatala vodu. $\mathrm{Na}$ osnovu mnogobrojnih historijskih dokumenata, može se zaključiti da je Hasan-aga, povrede koje se spominju u baladi, zadobio u borbi sa kršćanskim odmetnicima (1645-69.). Kako 
kazuje balada, dok je ležao ranjen, njegova žena Fatima Arapović (rođ. Pintorović) ga nije nijednom "od stida" posjetila.

Međutim ta sintagma "od stida" se mora analizirati u skladu su tadašnjim strogim patrijarhalnim uređenjem, ali se pri tome ne smije zaboraviti ni stroga "kastinska" podjela koja vlada u bosanskome društvu. Međutim, na koji god način analizirali tu sintagmu, ona je dovela do toga da je Hasanaga u ponositoj ljutnji poslao ženi poruku da ga ne čeka na dvoru, te da se vrati svojoj majci u Klis. Hasanaginica ga, ipak, čeka i nada se da će se njen srditi muž predomisliti, ako ne zbog nje lično, onda zbog njihove djece, no on je po dolasku tjera sa dvora. Hronološki gledajući, to se najvjerojatnije dešava između 1645. i 1649. Fatimin brat, beg Pintorović, po kastinskom principu nadređen agi Arapoviću, duboko uvrijeđenog begovskog nama, mimo želje svoje sestre, ugovara njen brak sa "Imotskim kadijom". Po historijskim dokumentima, to je bio jedan od najbogatijih Imoćana, te je beg Pintorović htio izvući ličnu korist iz toga braka, ali, prije svega, i degradirati, "narodski ismijati" Hasana, "običnog agu", te mu pokazati da njegova sestra odlazi na bolje i da je on u suštini nikada i nije bio dostojan.

Ovakav nesretni splet okolnosti će Hasanaginicu gurnuti u emocionalnu provaliju. Ona postaje psihički slomljena žena koja najviše pati za svojom djecom. Kraj same balade je nadaleko poznat. Hasanaginica zaustavlja svatove pokraj dvora age Hasan-age, u želji da vidi djecu, da se oprosti od njih, ali i sa nadom u pozitivnu promjenu svoje situacije. Hasan-agina surovost upravo u tom momentu dolazi do kulminacije. On doziva djecu, obraća im se riječima: "sirotice moje koje majka neće ni da pogleda." Srce nesretne žene i nesretne majke nije moglo više da izdrži, te ona pada na zemlju i umire od bola i nepravde, gledajuću u svoju djecu, ali i u svoga okrutnoga muža ("Usput se je s dušom rastavila. Od žalosti gledajuć sirote!").

I kada se saberu historijski dokumenti, narodne legende i podaci koje nam donosi sama balada, teško je znati šta se od ovoga stvarno dogodilo, a šta je "narod pridodao". Možda su se događaji odvijali autentično onima u baladi, a možda se u stvarnosti desi samo poneki fragment od svega onog ispjevanog $\mathrm{i}$ ispripovijedanog. Ipak, bez obzira na nejasnu granicu između historije i mita, zna se pouzdano da su sljedeće osobe stvarno postojale: 
Hasan Arapović - Hasanaga, vjerojatno graničar tadašnje bosanske države, Hasanaginica - Fatima Arapović (rođ. Pintorović), Hasan-agina žena, beg Pintorović, brat Fatime Arapović.

Bošnjački književnik Alija Isaković je iznio zanimljivu konstataciju, napola u šali, da je baladu mogla napisati i sama Hasanaginica (Fatima Arapović) nemajući kome drugom da ispriča svoju bol i patnju za djecom. Imajući u vidu otvorenost naše usmene književnosti, ni ta se mogućnost ne bi trebala isključiti. U njegovoj drami Hasanaginica, scena je napravljena tako da paralelno omogućuje odvijanje dvije radnje, lijevo je kula bega Pintorovića na Klisu, a desno je odaja u kuli Hasan-age u Zagvozdu.

Da bi se prikazala izražena socijalna razlika, odaja age Hasanage je znatno skromnije namještene. Samom podjelom scene na dva suprotstavljena dijela već scenskom postavkom se začinje dramski sukob koji leži u antagonizmu dvije različite socijalne klase predstavljene u begovima Pintorovićima i agama Arapovićima. Intimna drama ovdje proizlazi iz socijalnih sukoba koji će uroditi tragedijom. Pregrađivanjem scenskog prostora postiže se neposredna prezentacija simultanih zbivanja na različitim mjestima. Vertikalno pregrađena pozornica na dva dijela, begovske odaje i aginske odaje, sa dijelom simultanim, dijelom sukcesivnim događanjima, na proračunat način postiže se jak kontrast koji ukazuje na nepremostive socijalne razlike, na ustaljenu napetost između bogatijih i siromašnijih, plemenitih i onih manje plemenitih, između gornjeg i donjeg dijela društvenog sloja. Osim ove scenske podijeljenosti, kao dva zasebna segmenta na kojima je poseban akcent vizualnog sloja, javljaju se šator age Hasanage na početku drame i svadbena povorka na samom kraju drame, i oni kao da uokviruju konstantnu podijeljenu scenu u cjelovito dorečenu dramsku poruku.

Sam brak takvog tipa (preveliki klasni antagonizmi) je odmah u startu bio osuđen na propast, jer je to vrijeme postepenog propadanja begovska kaste, što je značilo da se pripadnici te kaste u to vrijeme najviše bore da očuvaju stari "nam" i obraz. Hasanaginica, kao žena, kao individua je tu potpuno isključena, ona je samo "vrijedna porodična roba" kojom trguju "stariji". Ni nakon njene udaje taj antagonizam nije prestao, nego je samo postajao još jači, dok nije došlo do banalnog razloga njegove eskalacije. Dakle, 
Isaković dramski sukob više gradi na društvenom, nego na intimnom planu i on nastoji da što racionalnije prikaže društveno-historijski kontekst koji je uvjetovao i intimnu tragediju koja je uzrokovala Hasanaginicinu tragičnu smrt. Kako je i autor naglasio u svom predgovoru, najveća želja pri pisanju ovog dramskog teksta mu je prvenstveno bila u tome da današnjeg čovjeka približi svim onim životnim okolnostima koje su uvjetovale tok događaja koje balada opisuje, pa tako Isaković dosljedno insistira i na narodnom jeziku toga doba.

Dosljedno književnoj kritici početkom 70-ih godina prošlog vijeka, Isaković demistificira dotadašnji stav da je osnovni uzrok tragedije "ženski stid", i istražuje dublji uzrok bračnog nesporazuma koji nije samo rezultat njenog stida i njegovog hira, već je između ostalog najbolji odraz kastinske nepremostive barijere.

"Ajkuna: "Ne mogu", reče nevjesta. Jera, pitam je. "Ne mogu od stida", reče Majka: Kakav stid, krmaluk begovski! Neće čoeku na noge! Ona je glava, a coek kapa!"

Osnovni antagonizam koji pokreće dramsku radnju su negativne konotacije koje proizlaze iz lika Hasanagina majke i bega Pintorovića, kao personifikacija svojih klasa.

Inače je karakterizacija likova $\mathrm{u}$ ovoj drami više $\mathrm{u}$ smislu funkcija pripadnosti svojoj klasi, nego u smislu izgrađivanja likova kao individualaca. Hasaniginica svekrva, naprosto ne može da probavi porijeklo svoje snahe i cijelo vrijeme između njih dvije ono stoji kao nepremostiva barijera. Ona je tipični primjer "zle svekrve" i ono po čemu Isaković odstupa od balade, jer za razliku od balade, ona u drami podstiče svoga sina da istjera Hasanaginicu.

"Majka: Nevjesta, uzmi se u pamet. Tvoje je da slušaš. Ako si i begovica, nisi se za nebo svezala. Tobe jarabi! Ovo je moj hal i moje ognjišce, dok je mene, beli. I nemoj mi kalem i jaziju prid oci. Sina sam izgubila, ha se tvojom

${ }^{1}$ Isaković, Alija: Hasanaginica, Drame, "Preporod", Sarajevo, 1995, str. 224. 
jazijom obandijao i sablju odviko! Ne zbori! Ti si sevep! Ja ili ti ovdi! Ne zbori! Sikter!'2

"Hasan-aga: A ti peškeš! Majko, ona je majka djece moje!

Majka: Sikter!

"Hasan-aga: A ti peškes!! Majko, ona je majka djece moje!

Majka: Sikter!

Hasan-aga: Ona je pod našim rzom i obrazom!

Majka: Sikter!

Hasan-aga:... Pod našim namom i imenom Arapovića.

Majka: Sikter, rekoh....'"

Hasaniginica naprosto ne može da funkcionira normalno, nju stalno koči nesretni splet djevojačkog i muževog prezimena, stalno uvjetujući njenu nesreću, i ona je nužno osuđena na tragediju. U očima svoje okoline ona postaje potpuno dehumanizirana kao obični predmet kastinskog sukobljavanja. Ona nema prava do odlučuje o bilo čemu i njene jedine odluke se svode na one koje su proizašle iz majčinske ljubav, koja je bila jača i od njenog begovskog nama, ali su to odluke koje će je ujedno i odvesti u smrt.

"Beg Pintorović (Prekida) Šta zborǐ̌, pjevaču?

Guslar: (Ne da se zbuniti)

Dočeka ga Vranić Ali-beže,

Isprid njega na noge skočio...

Beg Pintorović: (Ljut) Stani,ne valja ti pjesma. Kako može beg skakati na noge prid agom? Gdi to ima? Evo klǐskog kadije nek reče. ${ }^{\prime 4}$

\footnotetext{
2 Ibid. 223.

${ }^{3}$ Isaković, Alija: Hasanaginica, Drame, "Preporod", Sarajevo, 1995, str. 226.-227.

4 Ibid. 249.
} 
U ovom odlomku jesno je naglašeno da njegova begovska ponositost stoji iznad svega. Isaković je na vrlo uspješan način od baladne građe konstruirao dramski tekst koji u potpunosti dekonstruira socijalne uslove kao nepobitni faktori koji uzrokuju tragični splet okolnosti koji nužno vodi ka tragičnom nesporazumu između supružnika, a sami tim i prema tragičnom kraju glavne junakinje.

Zahvaljujući modernoj dramskoj konstrukciji koja uprkos tome odražava arhaične baladne elemente, ovaj dramski tekst nosi u sebi nešto od ljepote onog lirskog dijela balade i naprosto kipti emocijama. Isaković pri konstruiranju ove drame nastoji da suvremenog čovjeka što više približi vremenu, jeziku, ali i kulturološkim i socijalno-historijskim aspektima ove balade i bošnjačke tradicije. Na osnovu takve percepcije odnosa društvopozorište, pozorišne predstave postaju osnovni analitički modeli za preispitivanje socijalnih fenomena koji se čine kao oni koji najviše ugrožavaju i razbijaju društvenu koherenciju, a o kojima se manje ili više u otvorenim komunikativnim sistemima ne diskutira. Tako, dramski likovi postaju nositelji onih ukalupljenih društvenih karakteristika koje autori žele da dekonstruiraju i da ih kao takve, potpuno ili djelomično demistificirane, ponude na recepciju suvremenom društvu (dramskim recipijentima), u nadi da će postići kolektivnu recepciju sa kojom će društvo izliječiti od određenih " tipiziranih društvenih uloga", koje svojom statičnom egzistencijom ugrožavaju bivstvovanje evolutivnog društvenog sklada.

"...on pristupa gradi balade bez pretenzija da je dislocira kao bi je približio savremenom čovjeku, smatrajuci da je poštenije tog čovjeka približiti baladi, njenom vremenu, prostoru i ljudima. Preoblikovanje epskog materijala u dramski Isaković vrši na način stvaralački raspoloženog povjesničara $i$ u osvjetljavanju osnovnog problema kreće prvenstveno od socijalno-historijskih okolnosti, pa tragični nesporazum dvaju bića prebacuje sa intimnog na društveni plan. Stradanje Hasanaginice nije uslovljeno samo njenim stidom i Hasanaginim hirom, nego prije svega, njihovim kastinskim razlikama, pa tako Hasanaginica nije toliko žrtva moralnih običaja koliko jaza između aga i begova. ${ }^{\prime \prime 5}$

${ }^{5}$ Muzaferija, Gordana: Činiti za teatar, Centar za kulturu i obrazovanje, Tešanj, 2004, str.12. 
Tako neohistorijsko pozorište, kojem se priklanja i Alija Isaković, nastoji da nam ukaže na individualce (ili ljudsku grupu), koji su iznutra izlomljeni, koje historija/društvo slama da bi, eventualno, od njih proizvela više oblike čovječnosti, što predstavlja zanimljivu poetsku preporodnu metamorfozu. Tragika više nije konstruirana na plitkom ideološkom optimizmu (socreaalizam), već ona postaje direktan korelat individualizacije, obično povezane sa revolucionarnim aktivizmom, te je gotovo uvijek neposredna posljedica čovjekovog suočavanja sa neprijateljskom, surovo iskrenom historijom. U tako konstruiranom pozorištu sa političkom osovinom, ljudska sudbina se može prepoznati, doživjeti i razumjeti jedino kroz emanaciju i demistifikaciju historijske pozadine prezentirane epohe, dakle, jedino iz perspektive doba kojem ljudska sudbina pripada kao njen konstituirajući djelić. Ovakva novonastala pozorišna poetika nam nemilosrdno prezentira činjenicu koja je za svaku jedinku ljudskog društva nužna i nepromjenjiva sudbina, a to je egzistencija kroz simbiozu sa politikom, i sa historijom čovječanstva.

Osim Alije Isaković, estetski uspješnu preregistraciju narodne balade Hasanaginica u dramski tekst izvršio je i Nijaz Alispahić, koji je osim toga, na osnovu ovog svog dramskog teksta, napisao i libreto za prvu bosanskohercegovačku operu Hasanaginica, čiji je kompozitor bio Asim Horozić. Sam naslov drame Hasanaginica Nijaza Alispahića ima inkoativnu, referencijalnu i metatekstualnu funkciju, te uvodi recipijente drame u nadređenu perspektivu u odnosu na aktere dramskog prikazanja i daje određenu dozu dramske ironije koja proizlazi iz predznanja o radnji koja se scenski izvodi. Pored naslova, kao dio pomoćnog dramskog teksta javljaju se i podnaslovi koji su određeni za svaku scenu, a koji također imaju značajnu ulogu pri cjelokupnoj recepciji dramske prezentacije. Kod većine dramskih tekstova, koji se mogu okarakterisati kao historijski, naslov ima veoma značajnu ulogu pri samoj recepciji teksta i on se može posmatrati kao prva jaka pozicija u tekstu. Posebno je to značajno kod ove vrste drama, jer se one u većini baziraju na konkretnim historijskim ličnostima ili događajima, ili na jednoj od te dvije tematske okosnice. Tako naslov obično proizlazi iz toga $\mathrm{i}$ on ustvari ima ulogu da pruži prve $\mathrm{i}$ osnovne informacije o djelu koje će se čitati ili prezentovati na sceni. 
Dakle, sam naslov predstavlja presupoziciju, odnosno apriornu prvu informaciju, na osnovu koje se uspostavljaju temelji za dalju recepciju prezentiranog dramskog teksta. Ovo nužno podrazumijeva i dramsku ironiju, jer dramski recipijenti zahvaljujući naslovu već stvaraju predodređeni obzor očekivanja, te oni na osnovu svog iskustva prethodnih dramskih prezentacija i predznanja koje dobijaju na osnovu samog naslova predstave, imaju fond znanja koji ih stavlja u nadređenu funkciju u poznavanju dramskog sukoba u odnosu na fiktivne likove. Segmentacija dramskog teksta na pojedinačne dijelove (scene, međuprizore); "podnaslove" od kojih svaki može da funkcionira sam za sebe, i predstavlja "komad u komadu", je također svojevrsno epiziranje dramskog teksta, što djeluje na uključivanje recipijenata u samu unutrašnjost drame.

Autor ističe da dramski prolog nije neophodan i da se može i izostaviti, ali da je nužno da se pred sam početak izvođenja drame recitira balada. Kazivanje balade se treba izvesti pred zgradom pozorišta ili u holu pozorišta, kako to autor naglašava "među narodom". Kazivači balade su tipični dramatis personae koji nemaju nikakvog udjela u razvoju dramske radnje, pa je njihova uloga prvenstveno u epiziranju drame i u stvaranju unaprijed zadanog obzora očekivanja kod recipijenata drame. Međutim i oni su pomalo iskarikirani, jer su predstavljeni kao stari, antički ili možda mistični mudraci, koji su sveznajući i koji kroz dramski tok seciraju cjelokupnu radnju balade, te je pomalo i dekonstruiraju vrteći se u okosnici ironične opaske šta balada kaže i šta narod priča. Alispahić je tu iskoristio metodu modernog teatra koji uvlači gledateljstvo na scenu, i glumce sa scene među gledateljstvo, tako da se stvara jedna simbioza i pozornica postaje proširena i na publiku, te više nije samo daleki pijedestal, još daljih događanja.

On tako od pozorišta pravi ono što je Makluan označio kao ledeno hladni medij- medij u kojem publika biva ohrabrena da učestvuje u kreiranju, prijenosu i recepciji informacije koja se prezentuje na sceni. Na taj način se pokušava izazvati emocionalni šok gledateljstva, koje bi i samo trebalo da proživljava dramski sukob zajedno sa likovima ove drame. Svi ovi uvodni elementi imaju za funkciju ono što je Breht nazvao otuđenje, dakle, isijecanje iz sfere uobičajenosti, s ciljem da se na to isječeno skrene posebna 
kritička pažnja recipijenata. Po uzoru na brehtovski tip drame, autor nastoji što potpunije (realističnije) prikazati stvarnost postojećih društvenih odnosa koji su uslovili Hasanaginicinu tragediju, te se u kreiranju dramskog teksta koristi narodni, govorni jezik vremena o kojem govori, i koji sa svojim značajkama pripada društvenim, ali i individualnim osobinama likova, te se tako na poseban način ističe staleška pripadnost glavnih aktera drame. Kao i u svojoj drami Zmaj od Bosne, Alispahić uvodi dva zajedljiva pehlivna, Šahina i Tamburiju, koji svojim ironičnim komentarima pomalo ismijavaju svu ovu tragediju, tj. sam njen uzrok koji je u suštini apsurdan. Uvođenjem pehlivana koji stvaraju proturječnu informiranost između gledatelja i dramskih likova koristi se još od antike, ali je njen najpoznatiji dramski produktor Šekspir, pa ovu dramu možemo definirati kao pomalo šekspirijanski komponiranu, jer Alispahić koristi metodu discrepant awareness (prethodno recitiranje kompletne balade) uz pomoć koje stvara razliku u informiranosti između dramskih likova i publike, gdje su gledatelji ispred dramskih likova. Kako sam autor kaže, pored kazivača (glumaca) balade, tu su dvojica pehlivana (Šahin i Tamburija) koji vode priču i igru u predstavi. Oni i započinju igru sa ovim Prologom, dovodeći pod znak pitanja ono što govore kazivači, tj. narodna balada i ono što se u njoj kaže. Oni i publiku pozivaju u prostor u kojem će glumci "izigravati i predstavljati priču" o lijepoj Hasanaginici. Prolog ovdje ujedno predstavlja i epiziranje likovima unutar dramske igre, jer Šahin i Tamburija nisu dramatis personae, nego likovi koji se i sami nalaze u dramskoj situaciji, što konstruira specifičnu "personalnu uniju" dramskog lika i lika sa funkcijom epskog posredovanja.

Tako je Alispahić stvorio neke višeznačne i prelazne fenomene, kada lik izlazi iz dramske situacije i njene prostorno-vremenske uvjetovanosti komentira likove i događanja u drami. Oni nisu oni tipični pehlivani koji samo narativno deklamuju tok radnje, nego su oni vrlo zanimljivi gotovo dramatis personae likovi koji komentiraju, promišljaju u prosuđuje misli i postupke glavnih dramskih lica, što je jedan od metoda naturalističkog teatra u potrazi za neizrečenim mislima drame. Oni se pojavljuju tokom čitave dramske igre izvodeći različite igrarije, koje nekad sežu i do groteske "onog o čemu pjesma pjeva i onog o čemu se pripovijeda", ili prikazujući 
zbrkane i sukobljene tokove svijesti i savjesti. Njihova uloga se može poistovjetiti sa ulogom antičkog kora, oni su tu da komentiraju, da opominju, da podsjećaju, da podstiču tok dramskog zbivanja ili da vrše svojevrsnu retardaciju dramske radnje. Ovdje se polazi od ironične pretpostavke da se sumnja u mogućnost recipijentskog rasuđivanja ljudske drame koja se prezentuje, pa se ona intencijenalno podcrtava pehlivanskim komentarima i promišljanjima.

"Šahin: Čul' ti ovo?

Tamburija: Ja, budale, čojka!

Šahin: Haman sišo s uma.

Tamburija: 'Nakoj ženi tako nešto da poruči!'

Šahin: Ja budale čojka!

Tamburija: Haman sišo s uma aga Hasanaga!

Šahin: Slušaj ti mene, Tamburija! Ovo tamburanje meni ne miriše na dobro!"

Ovako strukturirana konstrukcija gledateljske nadmoći omogućuje višeznačnu recepciju drame, jer gledateljima omogućuje da spoznaju proturječnost informiranosti dramskih likova, te da tako i prosuđuju njihove postupke u svakoj dramskoj situaciji, što može stvoriti i efekta samozadovoljstva u komparaciji sa vlastitom egzistencijom. Upravo ovakav model discrepant awareness gledateljstva i otvara prostor za dramsku ironiju koja proizlazi iz simbioze nadmoćnog znanja i distanciranog simpatiziranja. Kazivači otvaraju dramsku igru, ali je ujedno isto tako i zatvaraju, svojim likom nas podsjećaju na neke antičke ili mistične mudrace i sav njihov tekst je poetski, ali ta poetika nije puna patosa, već je njena uloga suprotna, pa će oni emanirati one univerzalne dramske poruke, koje će tokom cijele drame lutati kroz našu svijest, da bi na kraju doživjele kulminaciju, kroz njihov etičko-egzistencijalni monolog, u kojem se tematizira nesavršenost svijeta i oplakuje njegova tragična struktura. Kao i u baladi dramski sukob je uvjetovan i predodređen socijalnim razlikama i neizbrisivim klišejima koji determiniraju Hasanagu kao osobu

${ }^{6}$ Alispahić, Nijaz: Hasanaginica, "PrintCom", Tuzla, 1999, str. 38.-39. 
do srži s tim iskompleksiranu i njegovog antagonistu Pintorović-bega, koji prelazi preko svega, ali ne i preko svoga begovskoga nama.

Hasanaginica nije ništa drugo, nego predmet preko kojeg se odvija sukob između kastinske podjele bosanskoga društva za vrijeme osmanlijske hijerarhije i ona kao takva nužno biva dovedena u ravan tragične junakinje kojoj ništa drugo ne preostaje, osim toga da se pomiri sa vlastitom sudbinom.

"Pintorović: Kadija se ni do danas nije oženio. Dva puta mi je dolazio. On te prosi i ja mu te dajem.

Hasanaginica: Brate!

Pintorović: Obećao. Pogovora nejma. Begovska je riječ pala. I tako će biti.

Hasanaginica: Zar baš mora, brate?

Pintorovic: Mora. Zapamtiće aginska fukara, kad mi je sestru unizila. I šta mogu Pintorović bezi, kad im se na obraz udari. "7

Alispahić se strogo pridržava baladnog toka radnje, ali uzima veliku slobodu u psihološkom relociranju likova i uvodi neke kojih u baladi uopće nema. Pored kazivača i pehlivana, tu je i baletni par, ali i likovi kao što su Jašar Suharija, Starac Fočo, Sazlija, a njihova osnovna dramska funkcija je da unose rasplamsavanje glumačke ekspresije. Lik Sultanije, najstarije kćerke, iskorišten je radi psihološkog produbljivanja radnje i prikazivanja svih onih dubokih psiholoških lomova koji se odvijaju u trokutu Hasanaginica-Hasanaga-Hasanagina majka. Kraj drame je otvoren iako se dramska radnja završava sa tragičnom smrću glavne junakinje, u epilogu se uvodi intertekstualno recitiranje stihova Maka Dizdara i autor naglašava u didaskalijama da predstava nikada ne završava i da je vječna kao i balada o lijepoj Hasanaginici. Tako je epilog ostavljen za koreografske igre u kojima je bitno, kako to autor ističe, naglasiti vječite etičke vrijednosti kojima odiše ova narodna balada.

${ }^{7}$ Alispahić, Nijaz: Hasanaginica, "PrintCom", Tuzla, 1999, str. 83. 


\section{Literatura:}

1. Alispahić, Nijaz, Hasanaginica, "PrintCom", Tuzla, 1999.

2. Isaković, Alija, Hasanaginica, Drame, "Preporod", Sarajevo, 1995.

3. Katnić-Bakaršić, Marina, Stilistika dramskog diskursa, Vrijeme, Zenica, 2003.

4. Lešić, Josip, Dramska književnost II, Institut za književnost/Svjetlost, Sarajevo, 1991.

5. Lešić, Josip, Savremena drama i pozorište u Bosni i Hercegovini, Sterijino pozorje, Novi Sad, 1984.

6. Lešić, Josip, Savremena dramska književnost u Bosni i Hercegovini (tema i struktura), U: Drame, Savremena književnost naroda i narodnosti BiH u 50 knjiga, Svjetlost, Sarajevo, 1985.

7. Lešić, Josip, Vrijeme prošlo - vrijeme sadašnje, Scena, 1970, br. 1-2.

8. Lešić, Zdenko, Nova čitanja. Poststrukturalistička čitanka, Buybook, Sarajevo, 2003.

9. Lešić, Zdenko, Teorija drame kroz stoljeća, Svjetlost, Sarajevo, 1977.

10. Melchinger, Siegfried, Povijest političkog kazališta, Grafički zavod Hrvatske, Zagreb, 1989.

11. Miočinović Mirjana: Moderna teorija drame, Nolit, Beograd, 1981.

12. Muzaferija, Gordana, Rizvanbegović, Fahrudin, Vujanović Vojislav: Antologija bošnjačke drame XX vijeka, Alef, Sarajevo, 2000.

13. Muzaferija, Gordana, Činiti za teatar, Centar za kulturu i obrazovanje, Tešanj, 2004.

14. Muzaferija, Gordana, Bošnjačka književnost u književnoj kritici, Novija književnost - Drama, Alef, Sarajevo, 1998.

15. Pfister, Manfred: Drama. Teorija i analiza, Hrvatski centar ITI, Zagreb, 1998.

16. Selenić, Slobodan, Dramski pravci XX veka, Umetnička akademija u Beogradu, Beograd, 1971.

17. Pavis, Patrice, Pojmovnik teatra, Izdanja antibarbarus, Zagreb, 2004.

18. Kraj utopije i pozorišta, Kritike i eseji (1985-2000), Otkrovenje, Beograd Sterijino pozorje, Novi Sad 2000. 
Amra Memic, PhD

\section{'HASANAGINICA' - ORAL BALLAD IN DRAMATIC ARTISTIC CREATION THROUGH THE EXAMPLE OD DRAMATIC TEXTS BY ALIJA ISAKOVIC AND NIJAZ ALISPAHIC}

\section{Abstract}

Historical background for dramatic texts about Hasanaginica are the most famous Bosniak folk ballads, and many, widespread legends and oral traditions. The very ballad about the unfortunate Hasanaginica was created in Imotska Krajina, and the main course of balladic action takes place in Vrdol (present-day Zagvozd and Župa) where Hasan-aga Arapovic, known for his famous heroism, had large estates and the tower, which he likely received through his widely famous warfare. Time of the events can be traced to the end of the first half of the seventeenth century, during the famous Cretan War, when there was changing and movement of the boundaries of the gigantic Ottoman Empire. The unfortunate combination of circumstances caused by primarily socio-cultural causes will push Hasanaginica into the emotional abyss and the tragic death of this woman-mother. And when you put together the historical documents, folk legends, and the data which is mentioned in the ballad itself, it is difficult to know what of this really happened, and what was "added by the folk". Perhaps the events were authentic to the ones in the ballad, and maybe only a fragment of all that which is sung and spoke about took place. However, such a profound tragedy, the painful death of an unfortunate woman-mother trapped in an unjust and rigid "caste" system, in which she acted only as a property and the object of the noble "us", whether it was a husband, or a brother, will found its ideal artistic re-registration in the Bosniak dramatic literature.

The two top Bosniak playwrighters, Alija Isakovic and Nijaz Alispahic, found their inspiration in this world famous ballad, which resulted in the emergence of two very significant historical drama texts, which occupy the peaks of this genre because of their aesthetic value, and also point out to an uninterrupted continuity and carefully nurtured traditional values of Bosniak literature in general. Both dramatic authors have masterfully used the specific constructive process of semantization of dramatic time, because the selection of any historical 
epoch has an exactly predetermined semantic function in the presentation of the dramatic text. Thankfully because of the multi-media nature of dramatic art, we have a parallel stream of two timeless figures and they are always in a form of symbiosis through the intersection of internal communication system with an external communication system.

Keywords: Hasanaginica, Hasan-aga Arapovic, Pintorovic-bey, Qadi from Imotski, the caste order, class and cultural boundaries, women as property, Alija Isakovic, Nijaz Alispahic, ballad, dramatic text, re-registration of discourse, semantization of dramatic time 


\section{الدكتورة عَمرة ميميتش^^}

قصيدة زوجة حسن آغا - القصة الشعرية الشفهية في الإنتاج الدرامي المتمثل في نموذج النصوص الدرامية لدى علي عيساكوفيتش ونياز علي سباهيتش الشي الئه

\section{خلاصة}

يعتبر الأساس التاريخي لنصوص درامية عن قصيدة زوجة حسن آغا أشهر قصية شعرية قومية بوشناقية، بالإضافة إلى الروايات الشفهية والأساطير الكثيرة المنتشرة. القصة الشعرية وحدها عن زوجة حسن آغا تكونت في منطقة "إيموتسكا كرايينا" والحدث الأسساسي يحدث في مكان اسماه "فردول" (واسماه اليوم "زاغفوزد" و و"جوبا")، حيث كان حسن آغا عرابوفيتش، المشهور بشجاعته يملك المزارع والقلاع التي حصل عليها

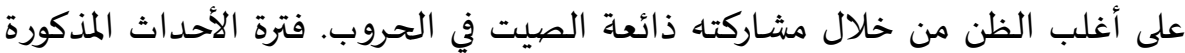



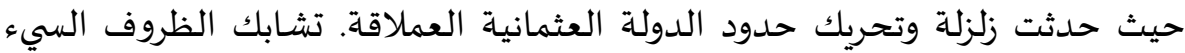

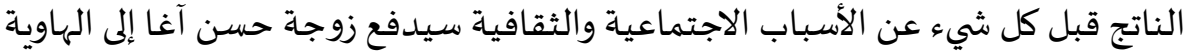

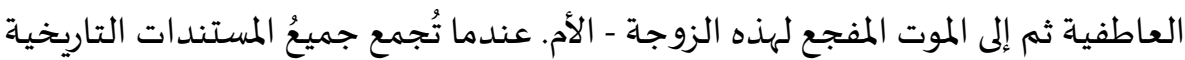

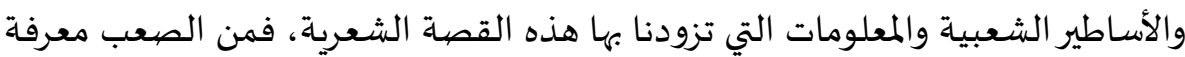
ماذا حدث بالفعل وماذا أضاف الناس إلى تلك القصية الشعرية. ربما كانت الأحداث

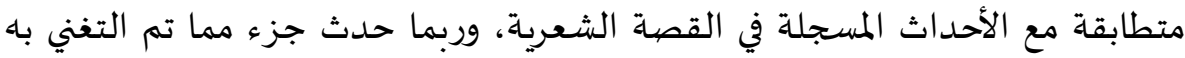

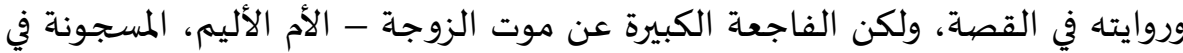

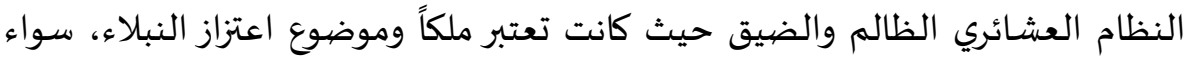
أكان ذلك يتعلق بالزوج أو الأخ، فإنها ستجد التغيير الفني المثالي في الأدب البوشناقي

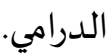

وجد الكاتبان البوشناقان المرموقان إلهامهما في هذه القصة المشهورة على مستوى عالمي وهما علي عيساكوفيتش ونياز علي سباهيتش، وعن ذلك نتج نصان دراميان تاريخيان مهمان يتبوآن قماة هذا النوع من الأعمال الأدبية بقيمتهما الجمالية. هذان وعين 
العملان يشيران كذلك إلى الاستمرارية غير المنقطعة والرعاية التي أحاطت قيمة الأدب



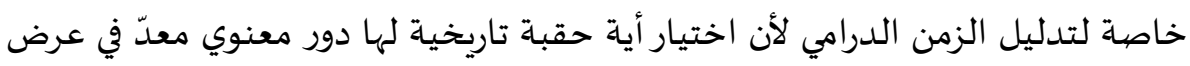

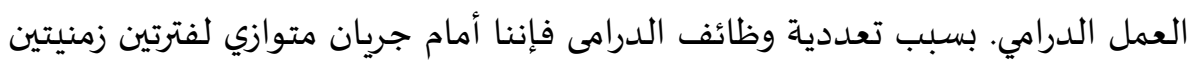
محددتين تتشابكان من خلال نظام الاتصال الداخلي والخارجي.

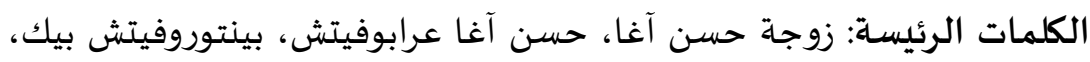

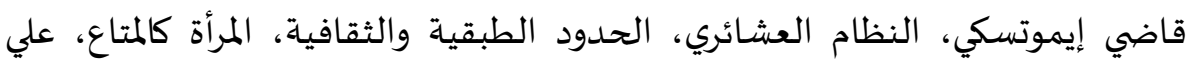

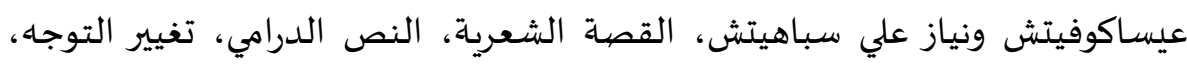
تدليل الزمن الدرامي. 